\title{
HABITAR/PERTENCER À CASA DE ADÍLIA LOPES: ESPAÇOS TEXTUAIS DISCURSIVO- MEMORIALÍSTICOS EM ESTAR EM CASA
}

TO DWELL/TO BELONG TO THE ADÍLIA LOPES' HOUSE:

MEMORIALIST DICURSIVE SPACES IN ESTAR EM CASA

Paulo Alberto da Silva Sales ${ }^{1}$

1 Docente no Programa de Pós-Graduação Stricto Sensu em Língua, Literatura e Interculturalidade da Universidade Estadual de Goiás, Campus Cora Coralina e pós-doutorando na Universidade Federal Fluminense (UFF).

Via Atlântica, Säo Paulo, n. 39, p. 326-358, set. 2021. doi: 10.11606/va.i39.181174 
Resumo: Apresenta-se uma leitura de alguns poemas do livro Estar em casa ${ }^{2}$ (2018), de Adília Lopes, nos quais a poeta se vale do espaço arquetípico do lar para construir uma poesia memorialístico-discursiva. Objetiva-se a examinar como alguns poemas dessa obra mobilizam espaços da casa que, no texto poético, são representados como lugar de recolhimento, de afirmação e de projeção do self da poeta a partir das experiências da habitação. Conclui-se que a ficcionalização dos elementos do lar feita por Adília torna seus poemas instituições vívidas, sejam eles relacionados aos elementos bioculturais, inconscientes, identitários e simbólicos.

Palavras-chave: Poesia portuguesa contemporânea, Adília Lopes, casa, habitação, memórias discursivas.

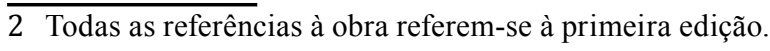


Abstract: It is presented a reading of some poems of the book Estar em casa (2018), by Adília Lopes in which the poet joins the home archetypal space to build a memorialist discursive poetry. It is examined how some poems of that work mobilize house spaces that at the poet text are represented as some places of retreat, affirmation and poet's self-protection by housing experiences. At the end of the paper, it noted that the fictionalization of home elements made by Adília becomes her poems vivid institutions, whatever they are related to biocultural, inconscient, identity and symbolic elements.

Keywords: Contemporary Portuguese poetry, Adília Lopes, house, housing, discursive memories. 
Habitar é, ao mesmo tempo, um evento e uma qualidade mental e experimental e um cenário funcional, material e técnico. A noção de lar se estende muito além da essência e seus limites físicos. Além dos aspectos práticos de residir, o ato de habitar é também um ato simbólico que, imperceptivelmente, organiza todo o mundo do habitante. Não apenas nossos corpos e necessidades físicas, mas também nossas mentes, memórias, sonhos e desejos devem ser acomodados e habitados. Habitar é parte do nosso próprio ser, de nossa identidade. (PALLASMAA, 2017, p. 8)

O ABISMO DENTRO DE CASA A meio da casa havia um poço sem fundo mas não havia perigo algum porque não vivia lá ninguém e ninguém ia lá. (LOPES, 2018, p. 47)

Antigamente havia

a casa de estar

e a casa de jantar

e havia fome

como hoje (LOPES, 2018, p. 77) 
As três epígrafes acima se interrelacionam no que diz respeito à relação entre poesia e habitação. A primeira, de caráter teórico, trata das expansões que o ato de habitar o espaço físico da casa propicia ao sujeito que nela reside. As outras duas são dois poemas que integram a obra Estar em casa, publicada em 2018, da poeta portuguesa Adília Lopes, as quais problematizam a relação entre sujeito e espaço domiciliar, bem como são exemplares de como os poemas da referida obra entrelaçam memórias discursivas e afetivas a outros intertextos.

Especificamente em "O abismo dentro de casa", que é um dos sessenta e três poemas que compõem o livro Estar em casa, nota-se uma relação íntima entre sujeito lírico e espaço domiciliar. Composto por apenas dois versos que, aparentemente, denotam um relato banal, esse poema causa estranhamento no leitor em uma primeira leitura, sobretudo, se nos determos na construção discursiva marcada pela brevidade e pela semelhança formal que lembra uma fábula e/ou conto de fadas. Todavia, o dístico traz consigo a "impropriedade substancial" (MARTELO, 2010, p. 9) do texto poético que se apropriou de discursos de outros saberes, fazendo com que a poesia lírica possa se expandir. Será por meio dessa expansão da poesia criada a partir dos elementos discursivos que integram o universo da casa - tais como os hipertextos, as lembranças afetivas, as memórias de leitura - e, sobretudo, por meio da ficcionalização de elementos au- 
tobiográficos vinculados à experiência da habitação e às referências aos espaços de Lisboa que leremos alguns poemas de Estar em casa.

Tanto no título do primeiro poema utilizado como epígrafe quanto no primeiro verso, a escolha dos símbolos 'poço sem fundo' e 'abismo' remetem às imagens que são projetadas no inconsciente e que desestruturam o caráter referencial descritivo-objetivo do poema. A casa de concreto desmaterializa-se e cede lugar às simbologias que o sujeito poético criou em suas vivências, principalmente ligadas ao imaginário infantil. 0 "desequilíbrio" intencional presente no poema - ao se valer de aspectos da prosa e de outros gêneros - seria, segundo Rosa Martelo (2010, p. 16), uma tentativa "de ver as palavras 'sem conceitos por trás' do que de reconhecer e explorar a possibilidade de deslocar, desequilibrar esses conceitos para fazer surgir, com uma força nova, a evidência do real - como se pudéssemos olhar para o mundo pela primeira vez".

Desenraizados de seus significados, os dois versos se aproximam do universo das histórias fantásticas, sobretudo àquelas ligadas ao aspecto lúdico e iniciadas pelo chavão "era uma vez...”. Ao término do segundo verso, o tom irônico presente em 'porque não vivia lá ninguém e ninguém ia lá' leva o leitor à associação do poema, em um primeiro momento, a uma linguagem simples e despretensiosa que é evidenciada pela voz "inocente" do sujeito lírico ao se referir ao objeto 
observado. Ironicamente, o leitor constatará, em uma segunda, terceira ou quarta leitura, que essa construção poética é composta de camadas discursivas que devem ser escavadas, semelhante à proposta foucaultiana apresentada no estudo $A$ arqueologia do saber $^{3}$ (2010). Adentrando no vão do "abismo", a superficialidade da primeira camada da linguagem se desfaz e o leitor se depara, então, com uma ácida crítica à própria condição do sujeito contemporâneo sem espaço na sociedade líquida.

Apreciada sob a óptica fenomenológica, a casa, segundo Juhani Pallasmaa (2017), sempre mantém uma relação íntima com a existência da vida do sujeito. Para esse autor, o ato de habitar uma casa, além de revelar as dimensões primordiais na relação entre sujeito/tempo/espaço, revela, sobretudo, “[...] o modo básico de alguém se relacionar com o mundo. É fundamentalmente um intercâmbio e uma extensão" (PALLASMAA, 2017, p. 7). O habitante, ao se acomodar nos ambientes domésticos, faz com que os espaços também se acomodem em sua consciência, se partirmos do pressuposto de que o lar não é um

3 Foucault, tanto em $A$ arqueologia do saber (2010) quanto em As palavras e as coisas (2007), elaborou uma série de noções (formações discursivas, positividade, arquivo) e definiu um domínio de análise (enunciados, campo enunciativo, práticas discursivas). $\mathrm{O}$ trabalho de escavação, nesse sentido, descreve os discursos como práticas específicas no elemento arquivo. Vistos sob esse prisma, os poemas de Adília não se apresentam como signos cristalizados e totalizantes, mas, sim, como significantes e acontecimentos puros que exigem a contramão interpretativa do/pelo leitor para a percepção da ironia e crítica latente de sua poesia. 
simples objeto ou construção civil, mas, sim, “[...] uma construção complexa e difusa, que integra memórias e imagens, desejos e medos, o passado e o presente" (PALLASMAA, 2017, p. 18).

Para a contemplação de uma "poética do lar", segundo o pensador finlandês, devemos associar a palavra lar à ideia de aconchego, de intimidade, de proteção e às memórias afetivas, principalmente aquelas ligadas à infância. Logo, esse verbete se torna um símbolo de proteção e ordem que, por sua vez, pode-se materializar, também, sob formas simbólicas de miséria humana, sobretudo por meio da solidão.

Esses diálogos intercambiantes entre a casa e o sujeito, nos quais o ato de habitar é visto como uma maneira de domesticar e controlar o tempo e o espaço, se destacam na poesia adiliana, especialmente em vários poemas de Estar em casa. Nessa obra, Adília constrói uma relação indissociável entre a habitação e a intimidade que, por sua vez, é apresentada de forma teatralizada em textos memorialísticos. As imagens, os espaços, os móveis e as lembranças de ambientes dentro e fora da casa, bem como de espaços da cidade de Lisboa, são articulados à construção fictícia que a poeta faz de si mesma, tais como se leem em "Sou deste lugar/como as árvores/e as casas" (LOPES, 2018, p. 38) e em:

Há uma lápide na fachada de um prédio lisboeta que diz que 
Fernando Pessoa viveu ali com a Tia Anica. Neste prédio existe

um colégio. Um amigo meu comentou que assim as crianças

podem ficar a pensar que Tia Anica do Fernando Pessoa é a Tia

Anica do Loulé.

1/1/17 (LOPES, 2018, p. 73)

Sem se deslocar do ambiente doméstico, a poesia de Adília mobiliza diferentes espaços textuais que se friccionam entre si. Os espaços intercambiantes - que vão desde espaços físicos aos universos ficcionais e de leituras variadas - evidenciam o trabalho vigilante da poeta que está atenta às textualidades diversas com as quais convive. Nos seus poemas, ao mobilizarem espaços da casa a espaços textuais diversos, nota-se um hibridismo pluridiscursivo que, também, se mescla às ficcionalizações de si. Em muitos textos, as referências aos espaços de leitura e da casa aparecem entrecruzados, em forma de jogos textuais e de trocadilhos. Destaca-se, ainda, nesses hibridismos, o trabalho linguístico feito por Adília, ao deslocar elementos sintáticos, semânticos, morfológicos e fonológicos em palavras justapostas e retomadas de discursos parodiados:

JARDIM DO TOREL

Este jardim

como a palma da mão 
Ao Sol à Lua

escrever

Jardim de areia

sob o Sol da Lua

A egípcia da entrada

saúda-nos

no meio do lago

Eclipse

elipse

José Estevão, 29 de Junho de 2016 (LOPES, 2018, p.

75)

As imagens presentes no poema "Jardim de Torel" revelam o hibridismo de referências discursivas que a poeta se apropria e as coloca em movimento. Imagens textuais são entrelaçadas a outras imagens de possíveis espaços da habitação da poeta, bem como a outros universos memorialísticos. No espaço do texto poético, Adília se vale, também, do deslocamento de espaços textuais que passam a integrar o imaginário das histórias com as quais a poeta se ficcionaliza. Em Estar em casa, não à toa, o arquétipo da habitação é colocado em primeiro plano e as diversas micronarrativas líricas que são narradas nunca saem do ambiente do lar. Esse espaço, o da casa, que é utilizada como arquétipo em sua poética, possui um "valor vivo" (BACHELARD, 1996, p. 73) justamente pelo fato dessa simbologia produzir imagens mentais múltiplas e que estão abrigadas no inconsciente coletivo, principalmente por meio da associação feita pelo su- 
jeito lírico aos ambientes internos, bem como aos móveis, aos objetos e às pessoas que nela habitaram. No poema transcrito acima, percebe-se que os espaços físicos se interrelacionam a espaços de leituras que, por sua vez, também se conectam a supostas vozes e/ou memórias discursivas do presente e do passado. Essa interioridade arquetípica da casa se entrelaça às várias lembranças do passado, principalmente aos momentos de leituras de diferentes textos feitos por Adília. Em seus poemas, destacam-se cosmovisões presentes, ao mesmo tempo, tanto na infância e quanto na adolescência de Maria José, a pessoa física por trás da persona Adília, ${ }^{4}$ bem como na idade adulta. A multiplicidade de assuntos, que vai desde reconstituições de momentos de aprendizado da poeta com sua mãe, com a avó materna, com tios, professores e outros sujeitos, bem como à apropriação de falas de pessoas comuns faz, na maioria das vezes, com que os poemas apresentem a dicção de crônicas de costumes: "A família vivia à custa da prima pobre. Todos roubavam a/ prima pobre. É assim: a pobreza é muito rica, a pobreza é ri-/queza, as almas caridosas que o digam" (LOPES, 2018, p. 45) e em "No gato no cão no periquito acredito/ em pessoas não acredito" (LOPES, 2018, p. 48). Martelo (2010), em "As armas desarmantes de Adília Lopes", ressalta o investimento

4 Rosa Martelo (2019), em “A luva e a mão (uma história de salvação)", examina o problema da criação de identidade autoral como processos libertários que vão em via oposta à identidade socialmente imposta e associada ao nome próprio. 
de Adília no desnudamento do autobiográfico e das histórias que compõem a Maria José para a criação de ficções de si mesma. Endossando os dizeres de Martelo, os poemas de Adília esmaecem os limites entre os discursos e os saberes, resultando em textos híbridos, inespecíficos e plurais. Por essa razão, é fundamental observar na leitura dos textos de Adília que

não há poesia sem verdade, mas também não há verdade sem prosaísmo, diz-nos então Adília. E isto obriga a procurar a poesia exatamente na vida quotidiana e comum, aí onde o sujeito se desenha nos antípodas daquela hiper-subjectividade que Paul Valéry considerou decorrer da experiência do poeta.[...] 0 contracto de leitura autobiográfica projectado pela poesia adiliana permite-lhe construir uma imagem de poetisa que, até certo ponto, inverte esta concepção: a sua seria a poesia de uma mulher biograficamente muito próxima dos padrões de uma vida vulgar, sem grande história, e a muitos níveis distante dos padrões convencionais do sucesso e também do "sussexo», para retomar um jogo de palavras adiliano. (MARTELO, 2010, p. 242)

Se a arte é vida, a poesia de Adília aposta em uma autofabulação de si para a criação de micronarrativas líricas que se assemelham - tomadas as devidas proporções - ao fenômeno surgido na França nos anos 1970 intitulado como autofiction, ou seja, uma ficcionalização do autor no texto ficcional. A principal característica desse tipo de texto é o embaralhamento das referências "estritamente reais", tal como quer Serge Doubrovski, criador do termo autoficção 
com a publicação do romance Fils (1977). Em Adília, os estratagemas autobiográficos são verificados em poemas multifacetados que representam, também, a fragmentação e a pluralidade do sujeito contemporâneo que escreve poesia. Memórias do passado são introjetadas na escrita do presente e, assim como na autoficção, o texto poético adiliano cria a ilusão da escrita momentânea do agora. No poema "Enterros", por exemplo, o sujeito poético rememora frases de sua mãe e de sua avó materna que se tornam importantes para a poeta na contemporaneidade:

\section{ENTERROS}

A minha mãe disse sempre que não deixava disposições para

depois de morrer porque não queria «dar trabalho aos que cá

ficam».

A minha avó materna disse sempre que não queria que lhe

dessem flores depois de morta. Se lhe queriam dar flores, que lhas

dessem em vida.

Acho isto saudável. Eu também penso assim.

10/7/16 (LOPES, 2018, p. 26)

Vinculados a uma dicção pueril, os poemas também incorporam questões de ordem fatídica da idade adulta, tais como a possível solidão da persona Adília ao lado de seus gatos, bem como dos próprios aspectos físicos dessa personagem que são tratados de 
forma irônica por vozes líricas, ao mesmo tempo, risíveis e reflexivas, como em: "Gosto muito de comparações. Escrevo muitas vezes a palavra/como. Como gosto muito de comer até tem mais graça" (LOPES, 2018, p. 19); "Só gosto de pessoas boas/quero lá saber que sejam inteligentes artistas sexy/sei lá o quê/ se não são boas pessoas/não prestam" (LOPES, 2018, p. 25) e em "Quis sempre/ter um namorado/e só um/o que me custava/era não ter nenhum" (LOPES, 2018, p. 21). 0 artifício da narrativização da poesia nesses versos possibilita que o poema se assemelhe a micorrelatos confessionais forjados, nos quais Adília, a persona multifacetada, se torne a peça central do jogo textual 5 . Em "Cómica”, o sujeito lírico joga com os elementos autobiográficos que estão introjetados na persona Adília e o leitor, por sua vez, constata que se trata de uma construção híbrida e irônica:

5 A respeito dessa questão, ver o estudo de Lúcia Liberato Evangelista (2011), intitulado Vida em comum: a poética de Adília Lopes. Nele, a autora examina a relação entre vida e poesia tentando articular o modo como essas duas estabelecem entre si uma passagem capaz de criar uma forma de realidade e um novo modo de articular a política. Para tanto, Evangelista se detém na investigação da escrita de Adília que, segundo a crítica, apresenta uma torção dos limites estabelecidos entre vida e poesia, realidade e ficção, política e poesia: "Isso porque ao mesmo tempo que trabalha com a exposição da vida privada, ao modo reality show, ou então, enquanto dramatiza o quotidiano de uma vida naïf de solteirona de classe média, Adília Lopes o faz utilizando estratégias textuais extremamente sofisticadas de releitura de uma vasta cultura artística, de reproblematização da identidade autoral e de desconstrução dos discursos correntes" (EVANGELISTA, 2011, p. 2). 


\section{CÓMICA}

Fui medir a tensão à farmácia. Despi uma manga do casaco

de malha. É um casaco que visto pouco. Quando voltei a vestir a

manga e a abotoar o casaco enganei-me por duas vezes seguidas a

abotoar o casaco. Chegava ao último botão junto ao pescoço e já

não tinha casa, faltava uma casa para o botão. Uma freguesa que

estava na farmácia riu-se a bandeiras despregadas da segunda vez

que eu não tinha casa para o botão. Como estou muito gorda,

senti-me o Bucha do Bucha e Estica a fazer gag. Tinha inven-

tado um gag por acaso. Senti-me contente. A farmacêutica disse

que, quando abotoa a bata, também lhe acontece $o$ mesmo. Foi

um momento divertido na farmácia. Nem vale a pena acrescen-

tar que a minha tensão estava boa. Haja saúde!

26/7/16 (LOPES, 2018, p. 61)

Em "Cómica”, é notório como Adília parece simular uma construção de fundo autobiográfica. Seus leitores se tornam íntimos da autora e passam a compartilhar de seus problemas. A dicção risível nos versos confirma o caráter fabular da construção da poeta no/pelo texto e, também, corrobora para a criação da ambiguidade intencional que leva o leitor a perceber que aquilo que ele está lendo não é tão simplista quanto parecer ser. Há mais coisas a serem es- 
miuçadas e os signos em Adília, assim como assinalou Deleuze (2010, p. 12) em Proust e os signos, não são vazios e gratuitos. Eles nos provocam "uma exaltação artificial, como signos mundanos. Também não são signos enganadores que nos fazem sofrer, como os do amor. [...] São signos verídicos que imediatamente nos dão a sensação de alegria incomum. São signos materiais". Nesta variedade de signos presentes em Adília, os poemas também não apresentam uma linha que os une no sentido de uma antologia. Os assuntos abordados - quase todos escritos em forma de pequenas narrativas - são apresentados em forma de estilhaços de memória afetiva que reconfiguram a subjetividade lírica por meio de justaposições diversas, sejam elas de cunho empírico e/ou de universos de leituras. Diversas descrições paradoxais, no que diz respeito à tentativa falha de uma reconstituição autobiográfica, evidenciam estruturas em série em forma de jogos textuais: um elemento autobiográfico dá sentido, por exemplo, a uma constatação de leitura feita por Adília. Os poemas "Em arroios" e "As flores baloiçam no ar", por exemplo, evidenciam essas mélanges de memórias afetivas e visuais que servem de substrato às lembranças de leituras e de aspectos dos primeiros escritos da poeta bem como de sua relação com a literatura hoje: 


\section{EM ARROIOS}

Aquiles Monteverde foi escritor didáctico e diplomata do sé-

culo XIX. Na placa com o nome da rua junto à Rua Rebelo da

Silva, didáctico está escrito sem o c antes do t. É extraordinário!

Está escrito segundo o Novo Acordo Ortográfico. Isto não acon-

tece escassos metros abaixo da placa junto à Rua de Arroios.

Acho que junto à Rebelo da Silva não está lá o c. Mas eu sou

Míope e não posso andar na rua com binóculos.

14/4/16 (LOPES, 2018, p. 22)

\section{AS FLORES BALOIÇAM NO AR}

Aos 10 anos entrei para a Escola Marquesa de Alorna. A

minha professora de Português era Maria Emília Caires. Um dos

primeiros exercícios do ano foi uma redacção. Eu escrevi qual-

quer coisa como «as flores baloiçam no ar». Achei que ia ter

Medíocre ou um Suf. Tive Bom. Fiquei muito contente e muito

surpreendida. Achava que «as flores baloiçam no ar» era um erro

de gramática. Era ainda mais grave: uma impostura, um erro de

moral, um pecado. Porque as flores não baloiçam no ar, os baloi-

ços baloiçam no ar, as flores não são baloiços.

Maria Emília Caires era uma professora maravilhosa. Eu tive

uma amigdalite e não pude ir às aulas. Adorava a escola. Foi um 
suplício para mim faltar às aulas. A professora Maria Emília en-

viou-me um bilhetinho a desejar-me as melhoras, lembro-me de

que falava "das marotas das anginas".

Talvez mesmo que do ponto de vista da Física as flores baloi-

cem no ar. Hoje está um dia de Junho maravilhoso e eu continuo

a achar que as flores baloiçam no ar. E a literatura continua a ser

para mim uma coisa muito séria. Literatura não é aldrabar, não é seduzir, seduzir é aldrabar.

Uma má professora dizia que literatura é enfeitar. Não é.

Só é enfeitar se for com boa intenção como quando uma criança

enfeita a árvore de Natal ou um amigo ou uma amiga faz um

embrulho bonito a uma prenda que nos oferece com carinho.

Literatura pode ser ternura, carinho. Textos pesados, muito ne-

gros, podem ser literatura ou podem ser treta, uma grande

treta.

1/6/17 (LOPES, 2018, p. $42-43$ )

Para além dos hibridismos discursivos e dos espaços textuais convocados nos poemas, nota-se também uma reflexão sobre o que seria a literatura, ou melhor, como a poeta entende essa arte, bem como são questionadas as práticas de ensino de literatura pouco exitosas, como é perceptível no poema "As flores baloiçam no ar". Tais poemas mobilizam, também, 
memórias discursivas de tempos relacionados tanto à infância quanto à idade adulta, em que se entrecruzam diferentes espaços de leitura feitos pela persona lírica: todos convergem na tentativa de definir uma possível identidade ao sujeito poético. Ao assumir dicções memorialísticas plurais, o texto poético adiliano, ironicamente, zomba da proposta de uma construção autobiográfica de segunda categoria. Aliás, em vários momentos de Estar em casa, é intencional a articulação de elementos da suposta casa da poeta - criada pelo/no texto - a partir de elementos que poderiam estar relacionados ao universo da pessoa física. A voz lírica mescla tempos e pontos de vista sobre a vida que não permitem a delimitação de uma identidade autoral e, tampouco, poética. Adília Lopes, a máscara, é ao mesmo tempo a Maria José, que é amante de gatos e que, por sua vez, traveste-se, por meio de discursos paródicos e em pastiche, de nomes e de estilos de autores da tradição. A menção a nomes de pessoas do convívio doméstico da poeta, bem como de animais, é constante em sua poesia. Destacamos, aqui, a presença dos felinos que aparecem nos poemas de Adília, não exclusivos da obra Estar em casa mas, também, abordados em livros anteriores. No poema "Autobiografia sumária de Adília Lopes", pertencente ao livro $A$ pão e água de colónia, de 1987, o sujeito poético joga com os limites de representação do eu ao embaralhar biografia/ficção no campo da lírica e, nessa problematização da identidade autoral, aparecem os felinos: 


\section{AUTOBIOGRAFIA SUMÁRIA DE ADÍLIA LOPES}

Os meus gatos

gostam de brincar

com as minhas baratas (LOPES, 2014, p. 71)

Em Estar em casa, é recorrente a figura da gata Lu - gata, essa, a quem a persona Adília dedicou o seu livro. A referência à gata aparece, ainda, no livro, em outros três poemas de cunho afetivo, nos quais verifica-se a importante relação de afeto e de companhia que o animal oferecia à personagem e, depois, a dor que lhe causa a sua perda: "A minha gata Lu/era mansa meiga bondosa macia/minha filha e minha mãe" (LOPES, 2018, p. 80); "A minha gata Lu morreu/está sempre viva/mas agora não lhe posso/dar festinhas" (LOPES, 2018, p. 81) e em

A Lu estava a morrer e quis ir para a janela apanhar Sol. De

repente estava a olhar com muita atenção o almeida a varrer as

folhas lá em baixo na rua.

De uma vez demorei-me demais, ao voltar para casa, a Lu pôs-

-me uma pata no peito com muita força. A Lu amava-me muito.

Acho que só os animais são capazes de amar assim tanto. Eu não

sou capaz.

6/10/16 (LOPES, 2018, p. 79) 
Ainda em um jogo de espelhamentos entre referências domésticas a intertextos diversos, Adília apresenta um outro poema que articula nomes dos bichanos a nomes de personalidades literárias. Os entrecruzamentos de tais referências alimentam o caráter híbrido de sua poesia, uma vez que o desejo da escritura, no sentido barthesiano do termo, é imitado na forma de escrever da poeta portuguesa. Transcrevemo-lo:

\section{QUATRO GATOS}

Na minha infância, lembro-me de quatro gatos. Nenhum deles

era meu. Havia o cavaquinho, o gato das vizinhas Botelhos, um

gato preto muito velhinho com uma coleira vermelha. Lembro-me

dele ao pé do aquecedor de petróleo. Havia o Piruças, um gato

tigre cinzento, muito vivo, muito esperto, novo, acho que também

tinha uma coleira vermelha. Entrava pela janela da cozinha, era do

prédio ao lado. A criada medonha ficava furiosa porque tinha su-

perstições. Acho que tinha medo de não se casar. Havia o gato do

Sr. José, o merceeiro da rua. Era um gato amarelo gordo, pachor-

rento. Dormia as sestas ao Sol na saliência do muro da cascata do

quintal do rés-do-chão. Teve a cauda doente, parecia uma salsicha

fresca, mas foi tratado com amor, andou com a calda entrapada. 
No $4^{\mathrm{o}}$ andar havia o Camões, um gato preto zarolho, acho que era

por ser zarolho que se chamava Camões. Tinha caído do $4 \stackrel{\mathrm{o}}{\mathrm{andar}}$,

feriu-se nas cordas, nos arames, dos estendais da roupa e ficou sem

um olho. Foi tratado no hospital da Escola de Medicina Veteriná-

ria. A dona, a Menina Maria, dizia que o gato tinha sido mais bem

tratado na Veterinária do que ela no hospital quando tinha sido

operada do estômago. As pessoas pobres eram muito mal tratadas

nos hospitais antes do 25 de Abril. Tive a sorte de crescer no Pátio

das Cantigas, na Aldeia da Roupa Branca. É por isso que sei tantas

coisas.

7/10/16 (LOPES, 2018, p. 37)

Outros poemas também retratam os deleites presentes no imaginário infantil associados à vida adulta da poeta. Esses vai e vens típicos dos poemas adilianos, em que as coisas se unem e acontecem sem uma explicação transcendental e que vão de uma temporalidade a outra, faz-nos lembrar, segundo Deleuze (2011), dos acontecimentos em séries, de paradoxos, como devir louco presentes no romance Alice no país das maravilhas (2009), de Lewis Carroll: "o paradoxo é, em primeiro lugar, o que destrói o bom senso como sentido único, mas, em seguida, o que destrói o senso comum como designação de identidades fixas" (DELEUZE, 2011, p. 3). Vistos como acontecimentos 
que substituem as dualidades, os poemas da autora de Dobra (2014) se inscrevem na fronteira entre as coisas e as proposições, ou seja, eles se firmam no entrelugar dos discursos. Imagens, deslocamentos e ultrapassagens que desterritorializam o sujeito se manifestam, ainda, em metapoemas que evidenciam o ato de leitura e o de criação poética: "Ler, escrever, ouvir música, andar a pé, brincar” (LOPES, 2018, p. 55) e em

Escreve poemas, pequena

escreve poemas

e come chocolates

e que os poemas

sejam como os chocolates

«Olha que não há mais metafísica no mundo senão chocolates»

Fernando Pessoa (LOPES, 2018, p. 74)

A predileção pela retomada do universo infanto-juvenil na vida adulta é confirmada em poemas nos quais a voz lírica expressa uma voz lúdica e entusiasmada: "Ser sempre criança" (LOPES, 2018, p. 36) e "A descer para baixo/no escorrega" (LOPES, 2018, p. 35). Esse retorno ao universo da casa e das vivências no ambiente familiar é reforçado tanto pelos poemas - em suas multifacetadas configurações - quanto pelos elementos externos a eles. Nas páginas iniciais da obra, há três fotografias que estão relacionadas ao suposto universo familiar de Adília. A primeira delas 
traz dois homens a tocar instrumentos musicais no ano de 1936. A um deles, Adília o nomeia como sendo o seu "avô Raul", uma referência familiar que apareceu em vários outros poemas dos livros Manhã e em Bandolim. As duas imagens seguintes indicam que se trata da poeta com seu pai no ano de $1964^{6}$. A última das fotografias registra Adília em uma calçada a caminhar junto aos pombos. A despeito desses registros, há um poema em específico de Estar em casa que representa um fato curioso. Trata-se de uma construção mista na qual se percebe o jogo textual adiliano que, levando-se em consideração a semântica da construção discursiva, pelas repetições de palavras e afirmações infantis, coloca em xeque uma possível identidade de quem escreve o poema. Ao mesmo tempo e no mesmo texto, aparecem versos que indicam um sujeito adulto e conhecedor das técnicas de criação poética. Esse poema em específico é intitulado "Ladrar":

\section{LADRAR}

A minha mãe imitava muito bem cães a ladrar. A minha avó,

mãe da minha mãe, contava que uma vez num comboio, a minha

mãe, quando era criança, imitou tão bem um cão a ladrar que o

revisor andou à procura do cão. Gosto de me lembrar disto. Tal-

vez já tenha escrito este haikai. (LOPES, 2018, p. 41)

6 A esse respeito, ver o estudo de Rosa Maria Martelo (2017) "Memórias da Infância na Poesia de Adília Lopes (Lirismo e autobiografia)". 
Esses elementos da memória, tanto afetiva quanto discursiva, invadem o universo da lírica na busca de uma representação de momentos diversos do universo infanto-juvenil e, também, da condição da poeta na sociedade pós-moderna. Poemas em forma de microrrelatos e mesmo como descrições de momentos vividos na infância são apresentados por meio de uma máscara que ora lembra a de uma criança que está atribuindo sentido às coisas que vê, ora uma visão crítica da sociedade a qual pertence. Essas sutilezas vão ao encontro do que Gaston Bachelard (2009) entende como o "maravilhar-se diante de novidades que reanimam origens", que então renova e redobra a alegria de maravilhar-se:

Ao maravilhar-se acrescenta-se, em poesia, a alegria de falar. Essa alegria, cumpre apreendê-la em sua absoluta positividade. A imagem poética, aparecendo como um novo ser da linguagem, em nada se compara, segundo o modo de uma metáfora comum, a uma válvula que se abriria para liberar instintos recalcados. A imagem poética ilumina com tal luz a consciência, que é vão procurar-lhe antecedentes inconscientes. [...] A poesia é um dos destinos da palavra. Tentando sutilizar a tomada de consciência da linguagem ao nível dos poemas, chegamos à impressão de que tocamos o homem da palavra nova, de uma palavra, de uma palavra que não se limita a exprimir ideias ou sensações, mas que tenta ter um futuro. Dir-se-ia que a imagem poética, em sua novidade, abre um porvir da linguagem. (BACHELARD, 2009, p. 3) 
Os novos seres da linguagem aos quais Bachelard se refere, além dos momentos de porvir e de abertura do poético, são verificados na poesia de Adília por meio das conexões discursivas a textos e elementos estranhos à lírica. Contudo, há um determinante comum que unifica esses entrecruzamentos: a ficcionalização de elementos autobiográficos na poesia, sobretudo aqueles relacionados, como destacamos, ao universo da casa e aos espaços textuais diversos. 0 poema a seguir, além de simular uma autobiografia, ainda se mescla a elementos da matemática e das ciências exatas:

\section{$54-45$}

No dia em que fiz 54 anos, tive um bolo de aniversário com

duas velas: uma com um 5 pintado e outra com um 4 pintado.

A vela com o 5 estava à esquerda da vela com o 4, claro. Mas uma

amiga na brincadeira, e talvez para me chamar velha, trocou a

posição das velas: a vela com o 4 ficou à esquerda e a vela com o

5 à direita. Sem raciocinar, ou raciocinando inconscientemente,

fiz a subtracção:

$54-45=9$

Sempre sem raciocinar, tive o palpite: para todos os números

entre 12 e 98, excepto as capicuas e os múltiplos de $10(20,30$,

40...) se fizermos a subtracção entre o número e o número que 
se obtém trocando os algarismos com que é escrito, obtemos um

múltiplo de 9.

Demonstrei assim:

$54=5 \times 10+4$

$45=4 \times 10+5$

Estes números de 12 a 98 podem sempre escrever-se, se de-

signarmos o da esquerda por a e o da direita por b:

$10 \times a+b$

E o número escrito ao contrário:

$10 \times b+a$

A subtracção é:

$10 \times a+b-(10 \times b+a)$

Que é igual a:

$10 \times a+b-10 \times b-a$

Ou seja:

$9 \times a-9 \times b$

$\mathrm{Ou}:$

$9 \times(a-b)$

Se $b$ for maior que $a$, devemos pensar em $a-b .0$ que inte-

ressa aqui é o par de números com os mesmos algarismos.

Alguns exemplos:

14 e $41 \quad 41-14=27=3 \times 9$

53 e $35 \quad 53-35=18=2 \times 9$

28 e $82 \quad 82-28=54=6 \times 9$

72 e $27 \quad 72-27=45=5 \times 9$

Sei que não sou Pascal! A net deve estar cheia de coisas des-

tas. $\mathrm{O}$ que acho engraçado é ter descoberto isto como descobri:

por acaso, por uma brincadeira com o bolo de aniversário.

3/7/16 (LOPES, 2018, p. 64 - 65)

Ao mesclar elementos da matemática, em particular, a uma autobiografia fingida, a poesia se expande 
e as interpretações são múltiplas. São esses entrecruzamentos discursivos que fascinam os leitores da poesia adiliana, poesia, essa, que se vale de memórias discursivas variadas. Os artifícios verbais e não verbais presentes na obra em questão são convidativos e aguçam os sentidos do leitor, induzindo-o a adentrar à casa da poeta e a compartilhar de suas felicidades, descobertas, desilusões e tristezas. Esse convite se inicia a partir do primeiro contato do leitor com a obra: os elementos visuais presentes da capa do livro, uma vez que todos eles povoam o universo do imaginário infantil: 
Figura 1. capa do livro Estar em casa

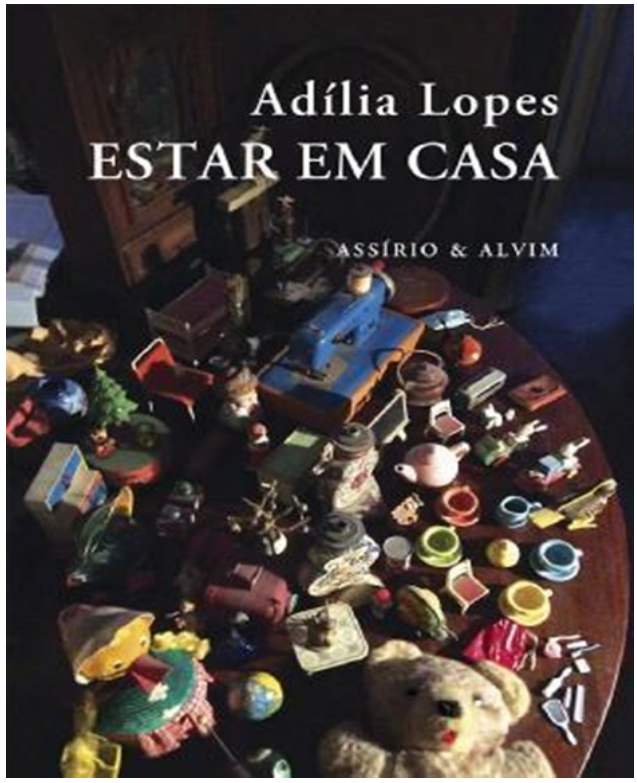

Fonte: LOPES, 2018

Na imagem, ao focalizar um ambiente íntimo, destacam-se, no primeiro plano, brinquedos de cores variadas e de tamanhos multiformes. Em contraste às cores vivas desses objetos, percebe-se a ambientação ao fundo escurecida e a luminosidade valoriza a contemplação de bonecos, de ursos de pelúcia, artefatos de bonecas e miniaturas que lembram réplicas de objetos e utensílios do lar, tais como bules, xícaras, pires 
e outros bibelôs. Aliás, os poemas "O bule" e "Baú" partem da experiência do olhar que contempla, por meio da rememoração, objetos infantis para que, então, o sujeito lírico passasse a ter outras visões das coisas e do mundo que o cerca:

\section{O BULE}

Tenho um bule de que gosto muito, que acho muito bonito.

Mas de repente do que eu gostei mais foi de reconhecer a sombra do

bule nas costas de uma cadeira, de dar com a sombra do bule. É

fácil dizer que lembra uma ave. Mas é o que está certo dizer. Essa

repentina ave, estou a lembrar um verso, deu-me muita paz. Ao

fim da tarde, depois de os amigos se terem ido embora, a sombra

do bule fez-me ver como sou feliz às vezes.

26/7/17 (LOPES, 2018, p. 59)

\section{BAÚ}

Um padre contou-me que uma paroquiana era pobre, não

tinha dinheiro para comprar bibelots para enfeitar a casa. Tinha

um baú em que guardava os bibelots que tinha, tirava de lá um

ou dois bibelots de cada vez para por em exposição, ia tirando os 
bibelots à vez para não ter todos os bibelots em exposição ao mesmo

tempo. Assim, era como se tivesse sempre bibelots novos,

quando tirava um bibelot do baú já não o via há tempo, já não se

lembrava muito bem dele, era como se fosse novidade. Um médico disse-me "a novidade estimula" e outro disse-me

"a capacidade de esquecimento das pessoas é muito grande".

Não é bom ser pobre mas é bom ter imaginação.

Os ricos não têm muita imaginação.

26/7/17 (LOPES, 2018, p. 62)

As experiências vivenciadas no passado e mesmo na contemporaneidade, obtidas por meio de diferentes contatos com os outros e com o mundo, possibilitam ao sujeito lírico adotar uma variedade de máscaras. O poema "Hotel em casa", ao contrário, apresenta uma situação interessante que é simulada por Adília. Nele, a poeta parece desconhecer lugares que, somente por meio do acesso aos bens de consumo, ela poderia conhecer. Trata-se de um poema cuja reflexão simula uma hipotética situação criada pela persona lírica:

\section{HOTEL EM CASA}

Uma amiga minha deu-me sabonetinhos, frasquinhos com

champôs e loções que dão de brinde nos hotéis. Uso-os em casa,

na casa de banho, como se estivesse na casa de banho de um 
quarto de hotel. Assim, com estes sabonetinhos e frasquinhos,

parece que estou num hotel sem sair de minha casa.

Não viajo,

não tenho dinheiro para viajar e já não gosto de viagens.

26/7/17 (LOPES, 2018, p. 60)

À guisa de conclusão, por meio da articulação de ambientes da casa a espaços de leituras diversas na obra Estar em casa, Adília segue a mesma linha de criação poética presente nas duas obras antecessoras, cuja escrita se vale do entrelaçamento entre espaços textuais discursivos e poesia. Por fim, vida, obra e crítica são "Memória/puzzle" (LOPES, 2018, p. $57)$ e os poemas funcionam como novos organismos autênticos, ou seja, "Poemas novos ovos" (LOPES, 2018, p. 56).

\section{Referências}

BACHELARD, Gaston. A poética do espaço. São Paulo: Martins Fontes, 1996. Tradução de Antônio da Costa Leal e Lídia do Valle Santos Leal.

BACHELARD, Gaston. A poética do devaneio. São Paulo: Martins Fontes, 2009. Tradução de Antonio de Pádua Danesi.

BARTHES, Roland. o prazer do texto. São Paulo: Perspectiva, 2010. Tradução de J. Guinsburg.

CARROLL, Lewis. Alice no país das maravilhas. São Paulo: Cosac \& Naify, 2009. Tradução de Nicolau Sevcenko.

DELEUZE, Gilles. Lógica do sentido. São Paulo: Perspectiva, 2011. Tradução de Luiz Roberto Salinas Fortes. 
DELEUZE, Gilles. Proust e os signos. Rio de Janeiro: Forense Universitária, 2010. Tradução de Antônio Carlos Piquet e Roberto Machado.

DELEUZE, Gilles; GUATTARI, Félix. 0 anti-édipo: capitalismo e esquizofrenia. São Paulo: Ed. 34, 2010. Tradução de Luiz B. L. Orlandi.

DERRIDA, Jacques. Gramatologia. São Paulo: Perspectiva, 2008. Tradução de Miriam Chnaiderman e Renato Janine Ribeiro.

DOUBROVSKY, Serge. Fils. Paris: Galilée, 1977.

EVANGELISTA, Lucia. Vida em comum: a poética de Adília Lopes. 139p. Dissertação (Mestrado) - Universidade do Porto. Porto, 2011.

FOUCAULT, Michel. A arqueologia do saber. Rio de Janeiro: Forense Universitária, 2010. Tradução de Luiz Felipe Baeta Neves.

LOPES, Adília. Bandolim. Porto: Assírio \& Alvim, 2016.

LOPES, Adília. Dias e Dias. Porto: Assírio \& Alvim, 2020.

LOPES, Adília. Dobra. Porto: Assírio \& Alvim, 2014.

LOPES, Adília. Estar em casa. Porto: Assírio \& Alvim, 2018. LOPES, Adília. Manhã. Porto: Assírio \& Alvim, 2015.

MARTELO, Rosa Maria. Poesia e des-equilíbrios. In: MARTELO, Rosa Maria. A forma informe: leituras de poesia. Lisboa: Assírio \& Alvim, 2010, p. 9 - 18.

MARTELO, Rosa Maria. As armas desarmantes de Adília Lopes. In: MARTELO, Rosa Maria. A forma informe: leituras de poesia. Lisboa: Assírio \& Alvim, 2010, p. 235 - 252. MARTELO, Rosa Maria. A luva e a mão (uma história de salvação). Elyra: Revista da Rede Internacional Lyracompoetics, n. 14, 2019, $49-65$.

MATELO, Rosa Maria. Memórias da infância na poesia de Adília Lopes (Lirismo e Autobiografia). Telhados de vidro, n. 22, p. 257-273, 2017.

PALLASMAA, Juhani. Habitar. São Paulo: Gustavo Gili, 2017. Tradução de Alexandre Salvaterra. 